\title{
Phenomenology, Lived Experience: Taking a Measure of the Topic ${ }^{1}$
}

\section{Robert Burch}

University of Alberta

In "On Phenomenology and its Practices" (Burch, 1989), I sketched the formal conditions under which phenomenology, as radical philosophy, is first intelligible and defensible. My purpose was to situate in principle the "whither" and "whereabouts" of phenomenological theorizing in order on that score to remedy my own philosophical and pedagogical ambivalence, as well as to find a philosophical vantage point from which to begin to mediate the conflicting expectations and outlooks of my students. On both counts, however, the attempt fell short. The ostensive reason was simple enough. Even in merely formal terms, I did not chart adequately the meaning of the phenomenological orientation I was sketching, with the result that the common ground I sought in theory remained to be discovered. To correct this shortcoming, my intention now is to consider in broad sweep three related themes set, but not developed, in the previous essay.

In this second article, I trace (albeit roughly) the fundamental determinations of lived experience in order to show how the phenomenological orientation sketched in "On Phenomenology and its Practices" (Burch, 1989) has a basis in the essence of the topic itself, namely, in lived experience as such. This provides that orientation with a formal legitimation. In the third article "Phenomenology and Human Science Research Reconsidered" (to be published in the next issue of Phenomenology + Pedago$g y$ ), I reconsider in terms of this legitimation the general meaning of phenomenological inquiry in order thereby to plot further the sense of its methodology. This makes clearer just how it is in principle that phenomenology maintains a perspective on the lived human experience. I also explore the implications of this perspective for phenomenologically oriented human science. This brings the discussion closer to our shared methodological concerns.

Admittedly, by means of such formal considerations alone the "truth" of phenomenology itself is not properly realized; for 
that ultimately depends on what is imaginatively disclosed and reflectively secured in the ongoing concrete phenomenological explorations of specific topics, including self-critical phenomenological reflection on the loci of these explorations themselves. Nor by such considerations is the requirement that we show how our theorizing practices are themselves "a relation of pedagogy" fulfilled; for that is truly established not in general by perfunctory theoretical assurances but individually in each pedagogical life as it is informed by such practices (cf. van Manen, 1986, p. 88). Nevertheless, such formal considerations do have a place. In advance of the exploration of any local topics or any question of the light cast by phenomenological theorizing on specific existential concerns, they serve to delineate, on the basis of what in principle is required by phenomenology's philosophical self-grounding, the essential domain in which any phenomenological investigation and any phenomenological pedagogy can and must move. Nothing in our practical aims and concerns ineluctably requires that we situate ourselves in this theoretical domain; but once we do, whatever those aims and concerns, the truth of our reconnaissance of the "things themselves" is inevitably constituted in part by the formal methodological demands of phenomenology itself as radical philosophy. In such "truth," moreover, lies the practical significance of phenomenology. A theorizing that was governed by a purely pragmatic measure of truth, pursued directly with a practical intent, and wholly geared to practical competence, would in effect leave everything essentially unchallenged (cf. Burch, 1987). Phenomenology, in contrast, does not simply copy or comply with the realm of ordinary practical knowledge and ends, but seeks to discover an underlying truth ordinarily concealed or distorted in that realm, a truth in terms of which the essential meaning of the practical has itself to be determined.

Still, from the perspective of the local discourse on "phenomenology and pedagogy," these formal issues are apt to seem tangential and even incestuously academic. For they are not concerned with what a pedagogically oriented theorist can make of phenomenology in the service of a transformative practice, but with what by its very nature a phenomenological orientation makes of any theorist who chooses to take direction from it. Here, the pedagogical interest is secondary and the practical intent is at a further remove. Nevertheless, this concern does point to a dimension of the relation of phenomenology and pedagogy that could do with a better reckoning. For as Grant (1986) reminds us, "philosophy always uses the user rather than he or she using it" (p. 71), and what lies on the tangent serves, usually without our precise knowing, to situate the center of our 
concerns. Moreover, in the pedagogical situations from which many of us actually write-not those situations out there and at home we typically write about, but the institutional contexts that inform our workaday practices and relationships, contexts structured not just by pedagogical ideals and concerns but also by the exigencies of political economy, the swings in intellectual fashion, the bureaucratic apparatus of courses, committees, dissertations, degrees, conferences, the competition for grants and funds, the prevailing demands for scientificity, and so forth-a thorough and systematic explication of where we stand methodologically belongs both to the critical reflection on our own "scientific" practices required as a part of the very process and legitimation of research and to our pedagogical responsibility to those whom we would accredit and direct along similar paths of inquiry.

\section{The Fundamental Determinations of Lived Experience and the Place of Phenomenology}

The locus of phenomenological reflection, its beginning and end, is the intelligibility of lived experience. Yet to English speakers the term "lived experience" is apt to sound rather odd. Heard in one way, it rings tautological-what might an experience be if it were not "lived"? Heard in another way, it suggests an evaluative stance, perhaps even a "jargon of authenticity"-though we all have experiences, only some of these for some of us are truly lived. The immediate difficulty is one of translation. The expression "lived experience" does not derive from English vernacular but enters our language via phenomenology and human science as a deliberate borrowing from philosophical German. In that discourse, the more common word for experience (i.e., Erfahrung) was early on assigned technical meanings (e.g., by Kant, 1929; \& Hegel, 1977) removed from everyday usage. To recover terminologically some of the mundane sense of experience as something one lives through personally, philosophers and biographers (c. 1870) coined from the verb erleben, meaning "to live to see," a noun Erlebnis (cf. Gadamer, 1975, p. 55). This neologism had on the face of it a twofold significance. According to its origin, it connoted what personally and immediately "one experiences for oneself," apart from all hearsay, conjecture, or imaginative and ratiocinatory constructions, and according to its nominal form, it connoted the persisting content of that experience (das Erlebte), "its discovered yield, its lasting residue" (Gadamer, 1975, p. 56). The etymological structure of Erlebnis suggested further a basic ontological meaning. In general, the prefix er signifies "from out of something according to its own essential measure," and Lebnis, the process and result of 
"living."2 Read in this way, Er-lebnis would mean more literally what unfolds and endures from life by virtue of life itself. When we recall that for Dilthey (1927, the philosopher first responsible for bringing the term Erlebnis into common academic usage), the word "life" (Leben) was a technical term that designated the distinctively human way of being, the basic phenomenological meaning of "lived experience" comes into better focus. In the first instance, the expression signifies in strictly ontological terms human experience as such, the original way in which human beings exist in the world as selves, and it implies that the essence of this experience lies precisely in its "lived" character. Moreover, the term suggesto that this lived character consists not simply in what is felt or undergone by sentient beings in the passage of time but of what from this passing sentience is meaningfully singled out and preserved. Regarded in this way, the naive intuitions of the English speaker appear less odd. The fact that the expression "lived experience" sounds to us tautological may be taken as a preliminary indication that its lived quality is of the very essence of experience and in some vague average way is always already understood within experience itself. The fact that the term "lived experience" also sounds evaluative may be taken as a preliminary indication that from the full range of possible self-feeling, lived experience amounts to something distinctive, a class of significant or memorable events, whose true meaning (if we listen to the past participial tone of the adjective) is something we come to recognize in retrospect.

Yet far from clarifying the fundamental determinations of lived experience, these linguistic ruminations uncover an original ambiguity. On the one hand, the "most basic form of lived experience involves our immediate, pre-reflective consciousness of life" (van Manen, 1990, p. 35), an immediacy that precedes all explicit retrospection, objectification, or recapitulation (cf. Gadamer, 1975, pp. 55-56). In this sense, "the reality of lived experience is there-for-me because I have a reflexive awareness of it," not because it is "perceived or represented" or made an object of thought (Dilthey, 1985, p. 223; quoted by van Manen, 1990). On the other hand, what has enough unity and determinateness to be $a$ lived experience is not reducible to fleeting impressions in the transience of awareness but is a unity of meaning, something which can be fixed and recollected as such. "What counts as a lived experience ... is meant as a unity ... [and] constitutes itself in memory" (Gadamer, 1975, p. 60). In this sense, then, "lived experience [Erlebnis] is actually a result [Ergebnis]" (Gadamer, 1985, p. 168). 
Some phenomenologists have attempted to reconcile this apparent tension between reflexive immediacy and explicit reflection by claiming that lived experience is bifurcated essentially along just these lines, with its lived character originating in immediacy and its meaning in reflection. Chief among these is Schutz. He writes (1967):

Meaning does not lie in the experience. Rather, those experiences are meaningful which are grasped reflectively.... It is, then, incorrect to say that my lived experiences are meaningful merely in virtue of their being experienced or lived through.... The reflective glance singles out an elapsed lived experience and constitutes it as meaningful. (pp. 69-71)

Their main thesis aside, these remarks help to focus two important points. "The living present in which I am borne along from each here and now to the next" (p. 70) does not have meaning purely and simply in itself, a sense that belongs to it as an objective property. Rather, the meaning of my experience is essentially something constituted; it lies in what is made of what is lived through. Moreover, the full meaning of experience is not simply given in the reflexive immediacy of the lived moment but emerges from explicit retrospection where meaning is recovered and reenacted, for example, in remembrance, narration, meditation, or more systematically, through phenomenological interpretation and "inscription." In his own analysis, however, Schutz so separates from the start "lived experience within the flow of duration and reflection on experience thus lived through" that the concrete unity of experience as both lived and meaningful is little more than caricatured. Thus, for example, he bases the "mineness" of what is "lived through" (p. 70; i.e., that in each case the experience is lived through directly and uniquely as one's own) simply on the "inner time-form" of consciousness (i.e., that in its internal structure each present moment of experience involves a retention of the past and a protention of the future). Yet he does not show how this time-form itself could ever suffice to make an experience "mine," other than as the structure of an experiential process in and through which I first make what I experience my own by constituting it as meaningful for me in one way or another. Schutz is then led to account for the "meaningfulness" of experience beyond what is lived through by hypostasizing a self-identical Ego "that looks at its experience and thereby renders it meaningful" (p. 70). Yet he does not show how this Ego is itself constituted in experience, nor then how in its self-constitution it is one with (as it must be) the self on whose experience it reflects. 


\section{Lived Experience as a Self-Constituting Pracess}

Even at the most rudimentary level, the lived character of experience lies in something more than mere sentience, selffeeling, or passing awareness, however intensely these may be undergone by an organism from instant to instant. What is merely felt at any moment will in the very next moment disintegrate into nothing, having in itself no determinate or determinable relation to a suite of such moments in which it can be preserved, nor then to the life of the sentient being that undergoes it. It is for all that no less felt in the instant, but it is not "lived through," for it cannot be situated as one's own, that is, as a distinct, retrievable moment in the course of one's personal life. To be "lived," experience must constitute originally an integral "sense," that is, an immanent intelligibility in terms of which in the very process of experience the varied moments are ordered, unified, and related by the experiencing self both to itself and to each other, a sense which then makes up the immediate course of that self's experiential life. Without this implicitly established sense, a stream of consciousness would never amount to one's own stream of consciousness in the first place, nor have any coherent moments which after the fact could be singled out and recovered as belonging to one's own past experience. It is only in virtue of what in principle is recollectable that an experienced content is experienceable, and what is recollectable must always already have been constituted as meaningful. In constituting this meaning, moreover, the experiencing self is implicated essentially in the constitutive process. It is aware of its self-identity and hence is a "self" only insofar as it constitutes the content of experience into a coherent sense as its own and thereby constitutes itself. At its origin, lived experience is a self-constituting (and hence dialectical) process.

On the one hand, then, the contents of consciousness in lived experience relate to oneself, that is, to the unity of one's conscious life, in a specific way. In each case, a lived experience is always essentially one's own direct experience, a moment in the suite of occurrences that make up a personal life. The relation to the experiencing self, to the structural nexus of its ongoing existence, is an essential determinant of the meaning of the experience. "Everything experienced [Erlebte] is experienced through oneself [Selbsterlebtes], and this in part constitutes its meaning, that it belongs to the unity of this self and thereby contains a distinctive and irreplaceable relation to the whole of this one life" (Gadamer, 1975, p. 60). The lived character of experience is thus one with its being "mine." But experience can 
be mine only insofar as I constitute it as mine, bringing it meaningfully to be and making it my own, integrating and reintegrating the constituted meaning into the course of my life. This happens, moreover, not just now and again in privileged moments of explicit reflection but always and at many different levels as an integral dimension of the whole ongoing process of lived experience. To the intelligibility of lived experience belongs originally the lived experience of intelligibility. On those occasions when I do deliberately turn my reflective glance on experiences past, I do not then make them meaningful for the very first time, but restore or alter meanings already implicit in their original sense, though unexplored or unexplorable in the rush of things. The meanings thus recovered may or may not disclose more truly who we are and where we stand. For in our explicit reflection we are as apt to tell ourselves "tales" in order, for example, to salvage our pride or sanity, or to come under the sway of the tales that others tell of us, as to recover more originally and inclusively what has been. Either way, such meanings may then be incorporated back into the immediate intelligibility of lived experience as we come to be guided more or less as a matter of course by the explicit narratives we have come to assume as our own. Nevertheless, before any such reflection and retelling or any such narrative appropriation and redirection, an implicit sense must always already have been constituted in the course of lived experience as a condition of its being lived.

On the other hand, as I bring the content of lived experience meaningfully to be and make it my own, in the very same act I also bring myself to be, defining myself essentially and establishing my own self-identity in relation to this constituted content. I do not simply have lived experiences as a given Ego which looks on a stream of duration and gives it personal meaning and unity. Rather, I am my lived experience. My very selfhood is one with the process wherein I constitute meanings into the pattern of a singular life, appropriating them (literally $a d$ proprius "to one's self") in and as my own personal history. The source of my self-identity and the unity of my experience are thus neither external to nor wholly other than what I accomplish and unify in the course of lived experience itself. Accordingly,

a person should never be thought of as a thing or substance, which in some way would have capacities or power.... A person is rather the unity of living through [Er-lebens] which is experienced immediately in and with [unmittlebar miterlebte] our lived 
experiences - not a thing merely thought of behind and outside what is immediately experienced. (Scheler, 1980, p. 371)

It has been commonplace in much of modern philosophy to represent persons in just the "substantive" or "thingly" ways here disavowed, attempting to account for selfhood in terms, for example, of a given mental substance (res cogitans) posited by metaphysical reflection or a number of simple empirical processes exposed objectively by physiology and neuro-science. In either case, the reality "present-at-hand" (Heidegger, 1977a, pp. 42ff.) is assumed to ground "the unity of the living through." Yet precisely in being that of a self, this "unity" neither needs nor can have a ground wholly beyond and outside itself. For what is not essentially self-realizing (in both senses of "realize") and thus self-grounding is in that respect neither a self nor sufficient alone to account for selfhood. ${ }^{3}$ To invoke such a ground is not just mistaken, it is superfluous. The self of lived experience is its own self-becoming; this alone accounts for the unity of the living through. ${ }^{4}$ Self-identity is sui generis.

\section{Intentionality and Being Situated}

Yet to affirm that we are essentially self-constituting does not entail the manifest absurdity that we bring ourselves into being ex nihilo, nor the assumption that we simply generate from ourselves and thus transcend completely all of the conditions and limits of our selfhood. The self of lived experience is essentially "situated" and thus is both limited and enabled by conditions not wholly reducible to its self-defining freedom. Traditionally, phenomenology has attempted to chart the ways in which, at the level of the consciousness/object dichotomy, self and nonself are mutually implicated and limiting in terms of the thesis of "intentionality." Without committing ourselves in advance to any particular doctrine, we can derive some initial clues concerning the essential situatedness of lived experience by considering the fate of this attempt.

In the phenomenological literature, the thesis of "intentionality" is most often expressed by the formula "all consciousness is consciousness of something" (Merleau-Ponty, 1962, p. xvii). This is usually taken to define the essence of psychical as opposed to physical states, that "every psychical phenomena is characterized by ... the reference to a content, the directedness toward an object ... or immanent objectivity" (Brentano, 1928, p. 125). In a rough way, this characterization serves to distinguish all phenomenological or quasi-phenomenological approaches to lived experience from every form of materialism or biologism. It suggests that, as a necessary condition of lived 
experience, the experiencing self must both distinguish and relate itself to an experienced content and hence that there must be originally a certain reflexive "distance" between consciousness and its object that is irreducible to empirical processes. Though taken by phenomenology to be correct, this formula nonetheless falls short of a full-blown phenomenological truth. For it does not express radically enough the way in which, originally, self and world are reciprocally related and mutually dependent. To phenomenology, intentionality means further that "inner perception is impossible without outer perception, that the world, as a collection of connected phenomena, is anticipated in the consciousness of my unity, and is the means whereby I come into being as a consciousness" (Merleau-Ponty, $1962, \mathrm{p}$ xvii). A version of this thesis was first demonstrated by Kant (1929, pp. 244, 345ff.). He showed that the experiencing self first comes to be self-conscious only in relation to an actual world of independent objects, and that objects in themselves only come to be objects, that is, part of a system of experience, insofar as they are constituted as such by and for the experiencing subject. Yet even this does not suffice to disclose lived experience fundamentally. For in order first to become a subject and thus to posit a relation to an objective content for the sake of knowledge, a self must always already be implicated in the world and stand in a relation to existing things and other selves, a relation that positing consciousness does not itself produce. "What distinguishes intentionality ... is that the unity of the world, before being posited by knowledge in a specific act of identification, is 'lived' as ready-made or already there" (Merleau-Ponty, 1962, p. xvii).

On this reading, however, the thesis of intentionality still admits of two distinct lines of explication. According to the one, the possibility of a shared objective world is in principle immanent in the very meaning of any individual lived experience as part of its "transcendental" structure, that is, as part of the essential conditions of its possibility. Despite fundamental differences in approach and strategy, and even in how they conceive the constitution of this "transcendence," both Husserl (1970a) and Heidegger (1977a) argue in this way. Each claims that in the very possibility of one's original encounter with any discrete thing as such (e.g., with an object of outer perception, or a tool "ready-to-hand" [Heidegger, 1977a, pp. 66ff.]), a context of intersubjective meaning is always already presupposed.

Things, objects ... are "given" as being valid for us in each case ... in principle only in such a way that we are conscious of them as things or objects within the world horizon.... Anything given in a 
worldly manner brings the world horizon with it and becomes an object of consciousness in this way alone. (Husserl, 1970b, pp. $143,264)$

Whenever we encounter anything, the world has already been previously discovered, though not thematically. (Heidegger, 1977a, p. 83)

Herein lies the primary sense of Heidegger's familiar claim that human being is essentially a "being with" (pp. 117ff.) It is not that the being of any individual presupposes an actual though contingent relation to other actual human beings in proximity. Rather, it is that in itself and as such this being presupposes a context of disclosed meaning that is the ground for any possible intersubjective relations. "Being with" denotes in the first place a constitutive determination of the being of every individual, however in fact she may be related to others.

According to the other line of explication, the self of lived experience does presuppose directly the actuality of what is "other." It presupposes an actual relation to an independent material world disclosed as a more or less coherent context of embodied action. On this reasoning, explicit self-consciousness is not first given before the world as a transcendental limit but is realized only as an incarnate being, embedded in a material world as an agent and bound to that world in essential ways, actively encounters resistance and otherness and comes to distinguish itself for itself in and through this process. A human self without this actual experience of otherness would never become a self in the first place. Similarly, it is claimed that the self of lived experience also presupposes an actual "intersubjectivity," an original relation within the world to other embodied selves. For, along with its relation to material things,

a self is primordially open to other selves; and unless it were thus open it would never become a self at all. A child becomes an "I" in a relation of openness to a "Thou"; indeed, he knows the meaning of "Thou" before he knowg the meaning of "I." (Fackenheim, 1968, p. 240; cf. Buber, 1958)

Although distinguishable, these two lines of explication have a peculiar interdependence, corresponding to what Heidegger (1969) terms the "ontological difference ... between being and beings" (p. 27). Roughly put, this is the "difference" which obtains between whatever in thought and practice we can direct ourselves to as an object of consciousness and thereby grasp either literally or conceptually, and the englobing intelligibility in virtue of which possible objects of consciousness are always already understood and accessible as such (1977a, pp. 6-7). In 
these terms, unless a pragmatic and intersubjective world were always already implicated as such in the meaning of lived experience, no actual encounter with things and selves would be possible in the first place. For "the disclosedness of being alone makes possible the manifestness of beings" (1969, p. 23). Yet, unless there were actual relations to other things and selves within the world, this meaning would always remain an abstract, unfulfilled, and thus ultimately unrealized possibility. For "being never comes to presence without beings" (1955, p. 46). Taken in this way, the thesis of intentionality undercuts all Pyrrhonian doubts regarding the existence of the external world and other minds. For it shows that the basic truth of this world is both ontically and ontologically a precondition of selfhood and thus is not the result but the tacit assumption of all sceptical questions. "What interests us," then, "is not the reasons one can have to consider the existence of the world "uncertain," but "to know precisely what the being of the world means" (Merleau-Ponty, 1964a, p. 21).

The question of this "meaning" is inseparable in the first place from questions of corporeity and embodiment. In order first for one to become a self and to direct oneself consciously to objects (which means also to imagine objects, to make a distinction between the actual and the chimerical, and to question the veridicality of this or that perception), the actuality of the corporeal, both of the body in which one's reflexive awareness inheres and of the world of material things and other embodied selves to which, through one's body, one is related, must already be given, "apperceived within intentionality itself" (Lingis, 1986, p. 21). It is in and through "bodily" being itself that one first comes to exist in the world as a unique individual, open at once to oneself and to things, affected by things and able to take them in hand. "We are not first of all 'alive,' only then to have for that purpose an apparatus that we call 'the body'; rather we live in that we are embodied [wir leben, in dem wir leiben]" (Heidegger, 1961, p. 119). Yet the "body" in this sense is not originally an object or instrument in space, something that we simply have and which accompanies us as matter to a mental form or as a tool one has at one's disposal. Rather the body is the very "place" where, each for herself, one "brings into existence ... [and] takes upon herself, space, object or instrument" (Merleau-Ponty, 1962, p. 154). As the being of a self, however, the identity of bodily being involves an essential mediation. In the natural immediacy of organic existence, the sentient being is an indifferent identity of corporeal and pyschical, but precisely to that extent it is not yet a self and its experience is not yet lived as its own. Becoming a self entails in the very unity of bodily 
being an essential "moment" of opposition to corporeity, both to that of the external material world and in its recalcitrance to that of the body through which one acts. The embodied self establishes its self-identity and thus becomes a self as it relates to and ovencomes this opposition, actively negating the sheer otherness of the corporeal through labor and play, relating the varied aspects of embodied experience to the unity of one conscious life. The "place" of bodily being is thus not an objective determination of corporeity itself but is constituted only as corporeity enters into the self's self-constitution, the self's selfidentity being "mediated both by the opposition and the sublation [Aufhebung] of it" (Hegel, 1978, p. 403).

Though an essential dimension of the self's original situatedness, this dialectic of embodiment does not encompass, even in its beginnings, the whole of our self-constitution. To chart as such the full range of "factual" conditions that enter into and situate our selfhood, we need a more general perspective. I have already (Burch, 1989) sketched the boundaries of this topic:

A human situation is constituted in part from the contingent interplay of three limiting dimensions-natural events and the possibilities inherent in physical things (including our bodies); the possibilities that inhere in one's own antecedent accomplishments, actions, and experiences, as well as those of one's contemporaries and predecessors; and the a priori structures that define the human condition itself (e.g., natality, mortality, temporality, finitude, sociality, etc.). Yet these limiting conditions do not constitute a situation in the form of objective facts-natural, historical, anthropological-laid out before a detached knower (cf. Fackenheim, 1961). Rather, the very factuality of these limiting "facts," and thus the situating character of the situation they define, is itself constituted in a dialectical relation with our actions. (p. 207)

Insofar as it is self-constituting, and to that extent a self, the self of lived experience is never simply the product of factual conditions, however given and intractable these may seem objectively. Such conditions are indeed facts and thus do genuinely limit or enable one's selfhood. There are natural facts, those which derive from the recalcitrance of physical beings and events, of climate and geography, of one's own body. There are historical facts, those which derive from one's biography and the biographies of those whom one encounters directly or indirectly, from the communities and institutions that serve common action, from the traditions to which one has access and which effect one's present possibilities. And there are the anthropological facts that define the human condition itself, the 
untranscendable boundaries that delimit a priori the essential domain of all human self-constitution. Yet such facts are facts of one's selfhood and hence condition and situate one's self as such only as they enter explicitly or implicitly into one's selfconstitution. Thus, for example, that "all human beings are mortal" is a universal, objective truth about the human species, but mortality is a fact of one's selfhood only insofar as one's anticipation of the inevitable prospect of her death enters into and conditions one's way of being and understanding (cf. Heidegger, 1977a, pp. 235-267). A childhood injury may be an actual incident in one's biography, but it is a fact of one's selfhood only as it is implicated in one's present choices and actions. That one has detached retinas may suffice as a clinical account of blindness, but blindness is a fact of one's selfhood only as one has to make one's way sightless in a sighted world. In all of this, what are surveyed as facts pure and simple by object-knowledge are determined as facts of one's selfhood existentially/ontologically only insofar as they are in some way appropriated into lived experience and in virtue of this make up situating dimensions of one's self-being.

But just as such facts come to be facts only in relation to the self's self-constitution, there is no self-constitution, nor then any self as such, separate from the appropriation of such facts. A wholly undetermined self would not be a self at all, and because qua human our self-determination is not absolute, it can originate only in relation to limiting and enabling conditions beyond what the self freely produces from itself. In a justly famous text, Hegel (1977) offers an ideal-typical account of the origins of human selfhood, which helps to bring this dimension of the topic clearly into focus. He describes an original encounter and struggle for "recognition" between two incipient selves where, from the immediacy of natural existence, each one first comes to distinguish itself as such in and through a reciprocal relation to the other. "Self-consciousness," Hegel shows, "exists in and for itself when, and by the fact that, it so exists for another; that is, it exists only in being acknowledged" (p. 111). In this essential sense, however, "being-acknowledged" is not an occasional subjective "feeling" that comes after the fact of selfhood, a purely private experience of acknowledgment that a given self may have (and whose veridicality might therefore be dubious). It is rather an original situating fact of selfhood, a dimension of the "sociality" which from the start both limits and enables each self"s self-becoming. It thus comes before all conceptual divisions and relations of the ontological and the epistemological and all attempts to relate selves as objects in the world according to the logic of external and internal relations. 
Originally and in its own way each self is "a being-acknowledged [ein Anerkanntes]" (p. 111), the relation of mutual recognition belonging originally to its very selfhood. Being-acknowledged is thus prior existentially/ontologically to the feelings one is able to ascribe as such either directly to oneself or by inference to the other. It thus also comes before any introspective queries about one's own true feelings or about the true feelings of others, and hence before any epistemological questioning of the true mutuality of our relationships. Whatever one comes to think or feel about others, however much one comes to withdraw or engage them, whomever one becomes, there is a prior mutuality that grounds and situates these possibilities of self.

What Hegel (1977) discovers here concerning the relation of selfhood and sociality holds in principle for the other factual dimensions of the human condition. In their selfhood, human beings also come to be determined by, for example, natality, temporality, finitude, mortality, and so forth. Yet these determinations are not abstract properties which qua human a self simply has for the reason that human beings are objectively the sort of creatures who, for example, are begotten, live under the constraints of time, have limited powers to determine and control things, and who eventually die, and so forth. Rather they are situating dimensions of the anthropological context in which human selves come to be selves in the first place. As such, they hold not as objectivelimitations extrinsic and accidental to selfhood but as limits that belong to the very possibility of its concrete self-becoming, to what essentially it can make of itself. In this respect, then, philosophers are more apt to speak of a "universal human condition" than a "universal essence that would be human nature" (Sartre, 1970, p. 35), of "existentials" rather than "categories" (Heidegger, 1977a, p. 44), of "boundary situations" rather than "properties" (Jaspers, 1948, pp. 467ff.).

Hegel's (1977) description also brings into better focus the manner in which our self-constitution is limited and enabled by natural facts. It shows that in the first place the human self is not simply given as such but comes to be from an inchoate being within nature. Nature is presupposed in our selfhood as the primitive stuff of our bodily being, as the domain from which we first emerge as selves and which physically sustains (or threatens) us, and as a reality we appropriate, either directly through consumption and labor or indirectly through subjugation or community with other appropriating selves. In the encounter with other selves, nature also serves as the specific ontic ground 
on which embodied selves are able to meet, as well as the medium for the first expression of a distinctively human desire. That we are as natural beings subject to natural limitations is objectively ascertainable, but that we are situated essentially by natural facts is another matter. The latter both presupposes that we are bound to nature itself and yet in our self-constitution transcend the sheer givenness and determination of nature as a reality in itself. Hegel's ideal-typical description makes this plain. As he portrays it, the original encounter between the incipient selves must be so contentious that their lives are on the line. Moreover, what in extremis they contend for is not one of the natural goods (e.g., food, territory, a mate, group dominance) that creatures instinctively seek as a matter of survival. Rather, in direct opposition to such goods and instincts, they contend for a non-natural value (i.e., "prestige"), the process of whose realization constitutes a decisive step beyond the immediacy of natural conditions and circumstances. This reflects the distinctive "non-natural" character of human desire, namely, that it is not limited to natural needs and their finite satisfaction but without limit seeks "to abolish the otherness of the Other" (Hegel, 1977, p. 518), finding mediate satisfaction in the struggle with other desiring selves. ${ }^{6}$ There is, then, at the origin of our selfhood a transcendence of those common processes by which, according to organic drives and natural needs, beings act and react adaptively to their environment in species-specific ways. Were a being incapable of such transcendence, it would never realize itself as a self nor then be situated essentially. It might well be a determinate, sentient being, differentiated from others of its species by the contingent particularities of its material existence. As such it would exist in some or other habitat or environment, would be affected individually by the particular conditions of its physical surroundings and organic make-up, would preserve itself individually as a determinate organic existence in relation to immediate threats and resources, and within specific bounds might even behave in its own individually characteristic patterns. Yet, for all this, it would not be self-differentiating or self-realizing. Its development and determinateness would be simply a product of nature, either as a direct and unreflected instantiation of specific characteristics and potentials in contingent circumstances or a mutation on that order caused by other natural conditions. Yet only a being which realizes and differentiates itself essentially and establishes its own self-identity in a limiting relation to what is other is in its essence a situated being. For it, the particular natural facts which make possible its determinate 
existence in virtue of their being appropriated belong in their particularity to its very essence.

Though helpful in disclosing the anthropological and natural dimensions of lived experience, Hegel's (1977) description of the original encounter between incipient selves would not seem on the face of it to bring into the same sharp focus the essential place of historical facts. Indeed, by describing such a "primitive" and antisocial encounter, one might conclude that Hegel simply presupposes a specific primeval historical situation. Yet this conclusion is unwarranted. On Hegel's description, the encounter of incipient selves is not in the first place an historically situated encounter, nor then can it be located in any essential way in what we know of empirical history or paleoanthropic conditions. For the "selves" he describes ideal-typically are in the first place not yet selves and in that measure are "prehistorical" in an existential/ontological sense. Their becoming historical is one with their becoming selves, the meaning of their historicity being constituted in and through that movement. Just as existentially/ontologically there are no anthropological or natural facts both determinative essentially of the self yet wholly external to its self-constitution, neither in the same respect are there any such historical facts. On this account, then, to be historically determined amounts to more than simply undergoing changes over time. For a change simply undergone by an entity is in that respect not a determination of its selfhood, and what does not determine a self is in that respect not properly historical. We are more accustomed to speak of historicity on the basis of an assumed essential distinction between human actions and natural events (i.e., that the former are truly the product of free will and the latter of natural causality). On these terms, one would be historically conditioned to the extent that one's present free actions had in their particularity prerequisites in specific contingent local circumstances and events, that is, that they would depend, for instance, on specific possibilities opened up by one's own previous achievements and experiences, by the actions and accomplishments of others (either directly, or as deposited in things culturally through work or handed on in systems of symbols, interpretations, techniques, etc.), by the local particularities and vicissitudes of one's natural situation, or by the gratuitous event of a unique inspiration. Insofar as they differ both from the conditions imposed on us universally by our specific organic nature and from the limits of the human condition itself, these prerequisites might well be called "historical." Yet this does not mean that they would situate the self essentially. For were the potential to act freely merely a property of a fixed and given 
human nature, the particularities of what one does in exercising that potential would in themselves be accidental to our essential being, and the historical prerequisites of any such action would likewise in their particularity be external to who and what we truly are. Thus, whatever the changing conditions under which individuals may act, human being itself would on this account always and everywhere be unchangingly the same. But such an assumption is incompatible with what we have so far discovered concerning the essence of selfhood. A self is a self only as it determines itself as such and, in the process of its self-determination, its being a self simpliciter and its being this individual self constitute themselves in a concrete unity. Thus, in its essence, the self of lived experience is not just conditioned by history; it is historical.

Yet the historicity of the self has a still deeper ground. For the self's self-constitution does not lie just in its everyday actions but in the realization of englobing, integral meanings, the ongoing sense that constitutes the intelligible course of its lived experience. The mundane actions it performs, its willing of this or that determinate end, has its meaning and ground in relation to this intelligibility. Moreover, at both levels the temporality of the self-constituting process is itself historical. "History as happening is an acting and enduring which pass through the present, which are determined from out of the future, and which take over the past" (Heidegger, 1959, p. 44; cf. Fackenheim, 1961, p. 40). It is on these terms that the "memory" in which lived experience "constitutes itself" must ultimately be understood, that is, not as the present effect of past events but as a present act of recollection that appropriates and reenacts a past in the anticipation of a future. "Lived experience is a structural nexus which preserves the past as a 'presence' in the present" (Dilthey, 1985, p. 16). In this nexus, the temporal ecstases (i.e., past, present, future) constitute a "dynamic unity" (p. 225) whose forward movement integrates and reintegrates something of its past. Without this self-constituting unity, lived experience would not be lived, for it would be without immanent meaning. Yet, without immanent meaning, it would not be the experience of a self.

\section{Lived Experience and Being-in-the-World}

As a rule, nonphenomenological philosophers misunderstand this process altogether. ${ }^{7}$ They tend, for example, to abstract spurious objective moments from the temporal unity of lived experience like frames of film, and then puzzle about how these moments can be linked together to yield a self that is identical over time. From the same perspective, they also tend to abstract 
from the self's everyday engagement with what situates it, portraying experience as a passing spectacle for a disembodied subject. "The mind," Hume (1888) writes, "is a kind of theatre" and my selfhood "a bundle of perceptions" (p. 253). However plausible to sedentary philosophers (and film buffs), this image conceals the fact that meanings arise in lived experience first and foremost not from the passive perceptions of disinterested sight but from our active and embodied involvement in a surrounding and resisting world. The world is disclosed in the first place as the context of our motor projects, a champ d'action in Merleau-Ponty's (1962) phrase, wherein we are disclosed to ourselves in the first place as agents. "The 'material world' of epistemological analysis ... is an abstraction from the actual world in which we act" (Macmurray, 1956, p. 173), as is the mental subject receiving visual impressions at a distance for the sake of true beliefs an abstraction from the incarnate subject who, in contact with the world through all of its senses, strives to fulfill desires and purposes and discovers itself in the process.

In abstracting from agency and from the dynamic unity of lived experience, nonphenomenological philosophers also abstract from what is actually "immediate" in lived experience, attempting to trace its contents back to original sensory givens in the form of direct simple impressions or unequivocal objects disclosed prior to our practical and interpretive orientations. But the origins of lived experience lie in just these practical and interpretive orientations; hence there can be no lived immediacy prior to them. What comes first both temporally and ontologically are not pure data (i.e., bare sensations or mere things) to which specific concepts and meanings are then serially attached. Rather, from the ground up lived experience is inherently the experience of meanings. "Pure seeing and hearing are dogmatic abstractions.... Perception always grasps meaning" (Gadamer, 1975, p. 82). At one level, the force of this claim is clear. We do not as selves first perceive a "throng of sensations" (noises, tones, colors), nor a display of indifferent objects, but meaningful things in contexts of meaning. Even the so-called "booming, buzzing confusion" (James, 1890) ascribed to the newborn's awareness is inchoately articulated with meaning. Were it not, it would never become lived experience at all. "To hear a bare sound, we have ... to listen abstractly" (Heidegger, 1971a, p. 26). Even when what we encounter is unidentified, indeterminate, or "meaningless," these too are qualities of meaning that arise in relation to an already constituted field of meaning. 
On this account, the primary centers of resistance and reaction in lived experience are the originally meaningful realities of everyday practical involvement, those things which from the start are intelligible as something and encounterable as such in the proximal domain of our needs and actions (even where that practical involvement and action scarcely go beyond the instincts to suckle and to grasp, and are informed by little more than the basic needs for food, rest, warmth, and attention). Yet such things are intelligible as something and encounterable as such only in relation to a situating ground. To a point, this insight is confirmed by Gestalt psychology: "The figure depends for its characteristics upon the ground on which it appears. The ground serves as a framework in which the figure is suspended and thereby determines the figure" (Koffka, 1935, p. 124). This uncovers something of the "horizonal" constitution of lived experience. The ground makes possible the perception of a discrete object insofar as the individual perceived thing owes its meaning to the intelligible whole which situates it, whereupon the sense given by the whole can be centered and revealed in the thing. Yet insofar as it abstracts the figure/ground function from our practical involvement with things and locates the ground simply in the noematic backdrop of objectively perceived figures (i.e., in the perceptual field as a sum of tacitly perceived objects), this account is limited to showing that the perception of an individual object presupposes, as it were, an "horizonal" mosaic of juxtaposed objective values more or less in focus (e.g., that I perceive the individual book only in a field made up of lamps, pens, paper, desk, etc., in other words, a field of other tacitly perceived objects). In our practical involvement with things, however, this mosaic itself presupposes an englobing context of meaning that gives bounds to and completes the experience as a determinate aspect of my life, and from which this whole scene and the objects in it get their sense. Thus, for example, what I am now experiencing in moving my pen across the page is meaningful not in itself as something simply lived through in time, but in terms of a broader sense, namely, the task of writing a specific text and its constituent parts. It is in virtue of this sense that the instantaneous movements of my hand, my passing sensations, thoughts and feelings, indeed the totality of my transient awareness and its distractions, are gathered into the one activity that is this experience of writing. Without some such sense, these movements, thoughts, and so forth, could not be lived as my own, and hence they could not be as such, for they would have no "distinctive and irreplaceable" (Gadamer, 1975, p. 60) locus in my course of experience. It is in relation to this sense, moreover, that the motions of my hand 
constitute a lived experience of writing in this time and place and not something else (e.g., doodling, spastic reflex, etc.). It is also in relation to this sense that these movements, thoughts, and so forth enter or recede from my awareness (e.g., I am more or less aware of my pen according to how it serves or impedes my writing, or of the movement of my hand in the measure of my scriptive dexterity, or of the noise of typing next door and the beginning crick in my neck to the extent that my mind is on my work, etc.). Of course, such a sense may not be, and often is not, strictly homogeneous (i.e., I may be working out the next paragraph of this paper in my head, keeping an eye on the baby, and making tea all at the same time). Nor need it be ordered by the accomplishment of a determinate end whose realization is the specific intended culmination of my action (e.g., when I engage in something for no purpose beyond the action itself, or have no specific goal, or have a specific purpose that I expect someone else's action to realize for me, or have someone else's purposes inflicted on me-the latter being pedagogically the most prominent and contentious). Nor is every such purpose of a general type grounded in an identical sense (e.g., scrawling today's grocery list on my way out the door is not like trying to write a magnum opus in the British Museum Library, though all are, loosely speaking, instances of writing). Nor need this sense be constituted at only one level (e.g., the task of writing belongs to a multifold context of meanings, to worlds and subworlds of significance that go beyond and situate this particular project and that make up my hermeneutic situation). Nor need I (nor can I) explicitly grasp all that makes up the sense which truly situates my experience. Nevertheless, in all cases of lived experience, an englobing contextual sense is always already presupposed as the ground of that experience. The essence of lived experience is thus said to lie in "a certain perceptual field on the basis of a world [sur fond de monde]" (Merleau-Ponty, 1962, p. 241; my emphasis).

Insofar as it precedes and makes possible a perceptual field, the "world" is not a meaning added on to primitive perception but is its basic, constitutive dimension.

To have a world means to comport oneself toward it. To comport oneself toward the world, however, means to keep oneself $s 0$ free from what one encounters of the world that one is able to present it to oneself as it is. (Gadamer, 1975, p. 402, my emphasis; cf. Scheler, 1961, pp. 36-41)

Yet "freedom" in this sense involves more than simply a capacity we have within the world to initiate actions of our own choosing or to transform things pragmatically to meet posited 
ends. To be sure, freedom to present the world as it is does imply "the possibility of disengaging oneself temporarily from the vital urgencies and remaining free for activities which in themselves are not satisfaction of needs" (Ortega y Gasset, 1961, pp. 92-93), as well as a "movement" by which the self of lived experience "on its own account [is able] to take up and transform a de facto situation" (Merleau-Ponty, 1962, p. 169). What we accomplish in these respects does follow from our being free selves. Yet before it can either initiate or elude causality or imagine and pursue specific possibilities of what might otherwise be, the self of lived experience must first be a self. At this more fundamental level, its "freedom is the engagement in the disclosure of beings as such" (Heidegger, 1977b, p. 128). This freedom lies not in the initiation of particular actions but in an original projection of possibilities of meaning in the form of an englobing and integral context of significance. It is in virtue of this "projection," for the most part tacit and indeterminate, that the self of lived experience both transcends what pertains to beings themselves and defines itself as a self in and through this transcendence.

Now, "if one characterizes every way of behaving toward [Verhalten $z u$ ] beings as intentional, then intentionality is possible only on the basis of transcendence" (Heidegger, 1969, p. 29). But the reality transcended is not this or that thing, nor any random aggregate of objects amenable to empirical inventory. Rather, it "is always already ... beings in a totality [Seiende in einer Ganzheit]" (p. 39). It is on the basis of this transcendence that we are first able to be situated essentially in the midst of beings, to direct ourselves to them, whether practically or cognitively, and to be determined by them as selves. Transcendent meaning goes beyond to situate in totality all of the natural, historical, or anthropological facts that enter into our self-constitution and is the ultimate basis of their existential/ontological factuality. Because those "facts" do have a basis in beings in themselves, they never simply reduce to our understanding of beings in a totality. Yet it is only because the self's essential constitution lies in this understanding that a self can be situated and factually determined in the first place. Similarly, though in the first place the self of lived experience only comes to be in essential relation to these situating facts, ultimately, "the selfhood of the self ... lies in transcendence" (p. 105). It is

only in and through transcendence that we can distinguish and decide, within the realm of beings, who and how a "self" is and what it is not. Only insofar as it exists as a self, can a self direct 
itself to beings, that however must be surpassed beforehand.

(p. 39)

We are as selves limited and enabled essentially by natural, anthropological, and historical facts, insofar as these facts are appropriated into our selfhood, while remaining more than simply a product of our self-constitution. Yet these facts can be appropriated in the first place only on the basis of transcendence.

Because the transcendence of beings in a totality belongs to our self-constitution and makes possible any particular encounter with beings, this totality must in each case always already be understood as a whole. This is not to say that we must conceive it explicitly as such, or that its essential relation to our selfhood must itself be disclosed to us (Heidegger, 1969, p. 83). In the first place, our understanding of this totality is essentially tacit and vague precisely because, in making possible our being in the midst of beings, it necessarily "recedes from focus in favor of our involvements with the immediate objects of experience, cognition, and action" (Burch, 1989, p. 198). Moreover, for the very reason that it is the essential basis of intentionality, our understanding of beings in a totality could never be adequately rendered on the model of our cognition of beings themselves. We could not piece together such an understanding from what we come to know of beings, for in its essence this understanding always already surpasse beings as a whole and is presupposed in any such knowledge. Yet neither could it lie in a presumed knowledge of a metaphysical reality "in itself" that extends over all beings as such (e.g., a set of universal, categorical determinations of beings as beings that would hold independently of us and await our submissive grasp). For there is a "totality" only in the understanding of the self and that totality can be understood only as an understanding of it belongs essentially to the self's self-constitution (cf. pp. 197, 213, n. 5). In this respect, then, the totality and our understanding of it are the same. Yet, in their sameness, there is also difference, because the effective totality that grounds intentionality is always essentially latent. That our understanding of it is vague is not simply a negative characteristic of understanding to be overcome by more rigorous methods, as if the totality were something out there in itself to be grasped ever more distinctly and clearly. Rather, the latency of the totality is a positive quality that makes possible whatever can be brought into precise focus. In this respect, the totality of transcendent understanding always means more than what can be expressly posited in it. ${ }^{8}$ It is in this sense that we speak of this totality as a "world," that is, an ongoing latent 
"horizon" of meaning, whose "range is variable" (Heidegger, 1969 , p. 83), and within which the whole of our engagement with beings takes place. "That on the basis of which [woraufhin] human being transcends, we call the world, and we define transcendence as being-in-the-world" (p. 41). Insofar as the selfhood of the self in lived experience lies in transcendence, and transcendence is defined as being-in-the-world, what is meant by "lived experience" is our being-in-the-world. ${ }^{9}$ We are as selves situated in this world essentially under two conditions, namely, that our very selfhood lies in transcendence, while the meaning of this world as a world of meaning is, in both its essential latency and as a disclosure "of beings," always more than our mere product or conscious object.

\section{Lived Experience and Language}

Now, insofar as "language" is the very medium of intelligibility, the transcendence that is our lived experience is essentially "linguistic." It is for this reason (and not one of expediency) that "language is the primary means for the communication of phenomenological insights" (Barritt, Beekman, Bleeker, \& Mulderij, 1983, p. 141). This is not to say that lived experience always presupposes that one has learned to talk. "Our experience of the world is not accomplished only in our apprenticeship and use of language" (Gadamer, 1977, p. 90). There is, for example, a whole domain of preverbal experience-of gesture, expression, and movement, including "the first smile of the child" (Buytendijk, 1988)—that both precedes and later carries on alongside explicit discourse. But here the preverbal is not the same as the nonlinguistic. For in an essential sense, language is that in virtue of which a priori we are in the world and come to talk. "Language alone brings what is, as something that is, into the open for the first time. Where no language occurs essentially, there is no openness of what is" (Heidegger, 1971b, p. 73; cf. Gadamer, 1975, pp. 401-403). Here the coming to be of the "world" and the coming to be of language are one, there being no lived experience without language and no language without lived experience. In this sense, then, language is not something we invent but the ground of all invention. For "how could man ever have invented the power that pervades him, which alone enables him to be as man" (Heidegger, 1959, p. 156)?

Of course, to speak in such terms clearly involves an understanding of language that goes beyond our familiar conceptions. In principle, this understanding consists of two theses. The first concerns the priority of language as an integral context of meaning at the origin of lived experience. It holds that every discrete, articulable instance of meaning is not engendered in 
itself singly and serially but only by the differences among meanings (cf. Merleau-Ponty, 1964b, p. 49; 1973, p. 31), and hence that a system of meaning (langue, Bedeutsamkeit, world) precedes and makes possible any individual experience and recognition of meaning (parole, Bedeutung, thing). Second, to call such a context of meaning "linguistic," one has to show that our familiar conception of language, that is, as a specific tool we institute and have at our disposal for pointing at objects and serving thus as the means for information and communication, is rooted in a more original linguisticality. Without attempting to show this here, I can at least indicate the phenomenological strategy such a demonstration would require. First, the essence of language would have to be disclosed not simply as an object for abstract universal conception, but existentially in terms of our participation in language at the level of lived experience and human speaking, and all questions concerning "sense" and "reference," information and communication, codes, sign systems, and "symbolic forms," would have to be traced back to this ground. Second, at this level the priority of the "sign" as an all-purpose arbitrary means of designation would have to be challenged, showing instead that all signs presuppose an essential disclosure of that to which they point, that they "arise from a showing within whose realm and for whose purposes they can be as signs" (Heidegger, 1971b, p. 123; cf. Gadamer, 1975, p. 377). Third, phenomenology would need to demonstrate that all instrumental functions of language as a tool at hand for designation have a deeper ontological root in the form of an original "showing," the fundamental interpretive process in virtue of which things are first disclosed to us as such and as a whole. Language would thereby be revealed originally not as a thing "we create and possess but as the ongoing origination of meaning and hence as "the vehicle of truth" (Merleau-Ponty, 1973, p. 14), a process in which we are always already involved essentially as the locus and medium. "Understood in this way, human being would be bespoken by language" (Heidegger, 1971b, p. 192), and only secondarily would language be an instrument of designation that we control by attaching precise significations to fixed signs. At the basis of this whole strategy is a challenge to the theory of truth which underlies the instrumental view of language. According to that theory, the essential place of truth is the proposition and truth itself consists in correspondence, either of our speech with divine language or simply of our language with the things themselves. Phenomenology must show conversely that the place of the proposition (and indeed of all utterance) is truth, where truth is understood as the original disclosure of things as such and as a whole. This original dis- 
closure is one with the origination of meaning, such that at this level "truth" and "meaning" are the "same" (Heidegger, 1956, p. 217). On these terms, then, correspondence and all instrumental uses of language would be intelligible only from out of truth, and truth would be inseparable from the coming to be of language. ${ }^{10}$

If lived experience were not possessed of this essential linguisticality, then language would provide no particular clue as to its truth. Were that the case, then the specific phenomenological strategies that appeal to language (e.g., "tracing etymological sources" or "searching idiomatic phrases" [van Manen, 1990, p. 58-62]) would be without foundation. Such strategies make sense phenomenologically only if our discourse opens essentially on whom we are and where we are situated. To be sure, "in citing such evidence, one must avoid uninhibited word-mysticism. Nevertheless it is the ultimate business of philosophy to preserve the force of the most elemental words in which human being expresses itself"' (Heidegger, 1977a, p. 220). This is not to imply, however, that these elemental words precede all experience simply as abstract universal forms which, though spoken differently in different tongues, have in advance a fixed meaning and thus determine all experience a priori in a univocal way. "Rather, it is part of experience itself that it seeks and finds words that express it" (Gadamer, 1975, p. 377). The language of our being is realized as a concrete universal and is only actual as it is appropriated in a situation. In this respect, to speak of "original language" is not to invoke a transcendental "logic" that pertains to us essentially beyond all time and place. "There is no such thing as a natural language in the sense that it would be the language of human nature existing in itself without a destiny. All language is historical" (Heidegger, 1971b, p. 133).

\section{A Formal Legitimation}

Although much more could be done to sharpen the contours of this map of lived experience and to bring out its details through everyday examples and illustrations, enough territory has been charted to establish in principle how phenomenology has a ground in lived experience. The dimensions of this "grounding" correspond to the formal conditions of phenomenology as radical philosophy (Burch, 1989). On the one hand, phenomenology is genuinely possible only insofar as we always already (i.e., a priori) understand something of the truth of lived experience. But we can have such understanding, only if it pertains in some way to our very being. This is just what our map of lived experience shows. We are our lived experience, and lived experience is the realization of transcendent meaning. Hence we 
always already understand something of the truth of lived experience, because our very being lies in this understanding. On the other hand, phenomenology can in principle be necessary only if the meaning of lived experience goes beyond our direct experience of meaning. This too is what our map of lived experience shows. What situates and makes possible any lived experience, and every seeming "given" within it, is an elusive, englobing sense, presupposed essentially, but in truth always more than the meanings actually realized in the course of lived experience. This disjunction goes beyond the tension with which my analysis began, that is, beyond the inevitable interstices that lie between immediate experiencing and everyday ongoing reflection. It is the essential "difference" in the meaning of lived experience between its explicit content and its truth.

This grounding suggests a further ontological thesis concerning the self in lived experience. Insofar as lived experience is essentially a self-constituting process and in each case is always essentially one's own, it must have $a$ basis in the reflexivity of consciousness. Without reflexivity, there would be no self-identity, nor any appropriation of a multiplicity of experiences into the unity of a personal life. In this respect, a self could never be "made" by that which is other (whether it be by nature, history, other people, discursive formations, or even by God) and yet precisely in being so made still be a "self." This is not to deny on the one hand that conditions and circumstances can be such as to restrict one's possibilities for self-determination, even to threaten or obliterate selfhood itself, or on the other hand that they can be such as to enhance one's possibilities for self-determination, opening one to ways of being which could not be realized simply from one's own personal efforts. Yet a self that was simply the product of such circumstances and conditions would to that degree not be a self, the selfhood lying instead in what the self makes of itself in relation to such conditions and circumstances. In this sense, the question of who we are essentially in lived experience, "albeit roughly ... answers itself in terms of the ' $I$ ' itself, the 'subject,' the 'self'" (Heidegger, 1977a, p. 114), the giveness of the " $I$ " in "mere formal reflective awareness" being prima facie "indubitable" (p. 115; cf. Sartre, 1956, pp. 73-74). Yet, if my self-constitution depends on limiting factors that are both appropriated into my self-constitution yet as limiting are not appropriated absolutely, such that my lived experience always necessarily means more than what I explicitly understand and what enters into its self-constitution is more than what I reflexively posit in the course of it, then the ontological locus for understanding the self of lived experience is not limited by the giveness of the I. For that givenness too has 
its "ontological horizon" in virtue of which it is "determined" (Heidegger, 1977a, p. 116). Though as a self, a human being has reference to itself essentially, it is as human also implicated essentially in a reality that is "other." On this reading, then, phenomenology is not 80 Cartesian as to absolutize self-consciousness in such a way as to presume to gather everything of experience reflectively and without essential remainder into a fully self-transparent prise de conscience. Yet neither is it so "deconstructive" as to absolutize contexts of meaning in such a way as to dissolve all selfhood (and hence all reflexivity, intention, authorship, and factuality) into an anonymous play of signifiers. Between self-consciousness and the truth of lived experience, phenomenology recognizes both a difference and a priority, and it lives with that tension.

The foregoing sketch also justifies in formal terms the claim that "the place of phenomenology is essentially the phenomenology of place" (Burch, 1989, p. 208). This is not meant to suggest that spatial metaphors have some sort of priority in matters phenomenological. As Heidegger points out (1977a), the "dominance of "spatial representations" in our language and theories has its basis in "fallenness," that is, in our everyday preoccupation with what is at hand (p. 369), and hence must be overcome in a theorizing which seeks the truth of the everyday. Nor, by a blatant reversal of the tradition from Kant to Heidegger, is it meant to suggest that "outer" spatial experience has priority over "inner" temporal experience. Rather, to speak of "place" existentially/ontologically is to name the primary locus of the generation of meaning and the becoming of selfhood, the domain wherein both lived time and lived space originate, coming to be together in the horizon of our embodied existence. To begin by juxtaposing space and time and from the vantage point of the assumed self-certainty of consciousness to argue then for the priority of the one over the other is to abstract from the concrete origins of lived experience in the world. Phenomenological theorizing must be more radical and concrete. Its "topological" talk is thus only superficially metaphorical. It does "carry" us "over" from what is familiar in an everyday way to what lies hidden in that familiarity as its meaning and ground. Yet precisely in doing this, it is also not metaphorical in a deeper sense. For it does not carry us over to a domain outside lived experience but discloses more originally and inclusively the essential place of that experience, the realm from which all metaphors and all determinations of space and time arise. 
1. As with "On Phenomenology and its Practicee" (1989), the ideas in this article were first presented at a biweekly meeting of the "Human Science Circle," University of Alberta. I am again grateful to Professor Max van Manen for his comments on that occasion and to Professor Margaret van de Pitte for reading the penultimate draft. I am also grateful to Professor Alex Neill (Trinity University) for critical discussions of the whole project.

2. I am indebted to Professor Arnd Bohm (Carleton University) for this etymology and to Dr. H. Gustav Klaus (University of Osnabrlick) for general clarification of the meaning of Erlebnis.

3. In contrast to the main stream of Anglo-American philosophy, the doctrine of the self as self-constituting has been a central, if not the central, theme of post-Kantian continental philosophy from Fichte to the early Heidegger. We are told, for example, that: "The Ego posits itself" (Fichte); "We are what we do" (Hegel); "Human being is [ist] what it eats [isst]" (Feuerbach); "We are the product of our labour" (Marx); "We are what we will" (Nietzsche); "Human being chooses itself" (Sartre); "Our essence lies in existence" (Heidegger). The earliest and most succinct presentation of the argument in support of this doctrine is given by Fichte (1970, pp. 16ff.). Perhaps the best general discussion of the thesis is to be found in E.L. Fackenheim, Metaphysics and Historicity (1961).

4. This self-constituting unity comes before all first-person questions concerning the reliability of one's memory and the discontinuities of waking and sleeping, and before all third-person philosophers' puzzles about the identity of amnesiacs, reincarnates, or multiple personalities. It should also be considered in any genuine therapeutic questioning of mental disintegration and breakdown.

5. The term "intentionality" derives from the Latin intentio, a technical term in scholastic philosophy meaning the mind's capacity to direct itself knowingly to objects and states of affairs. In the broadest terms, phenomenologists mean by "intentionality" our original engagement with the world, how we are directed to things. It is only when that engagement is interpreted in terms of agency that the meaning of "intentionality"comes closer to everyday usage and refers, derivatively, to the fact that the significance of things in experience "depends on the use we intend to make of them" (Barritt, Beekman, Bleeker, \& Mulderij, 1983, p. 157).

6. By insisting on the radically contentious character of the original encounter, Hegel is not precluding out of hand all possible acknowledgement-of-self in relations of communion and love, nor the possibility of solicitous encounters, which occasion one or both of the selves involved to open beyond what they have been. $\mathrm{He}$ is claiming, however, that insofar as selfhood is not a natural given, its coming to be entails necessarily a "negative moment" where the self breaks with natural immediacy and first defines itself as such in relations of opposition and conflict. Put less ideal- 
typically, a baby first comes to be a self neither simply nor decisively in the immediate loving acknowledgment of its parents (though doubtless that enters into what self she becomes), but in expressions of wilfulness. Moreover, by insisting on the original "non-naturalness" of human desire, Hegel is not thereby denying the place of natural desires and their finite satisfaction. Rather he is suggesting that the distinctive aspect of human desire, in terms of which even our natural desires have their existential meaning, lies beyond the immediate fulfilment of organic needs and supersedes them. According to the distinctive character of their desire, human beinge can, for example, wilfully forgo food, can dominate others for the sake of domination itself, can remain unsatisfied by a superfluity of sensuous pleasures, and so forth.

7. In a different way, so too do some phenomenologists. I once attended a lecture by a renowned phenomenological psychologist who presumed to speak in intimate detail of the "lived experience" of a zygote travelling down the fallopian tube and implanting itself in the uterine wall. Some years later, I attended a conference where phenomenologists (in an odd melding of Lovelock's "Gaia hypothesis" with some programmatic ideas from Merleau-Ponty) spoke unabashedly of the tree's "lived experience" of us!

8. Jose Ortega y Gasset (1946) provides a splendid account of this issue through a reflection on the old saw "we cannot see the forest for the trees." He shows why this is always necessarily the case, since the forest is the ever latent context of meaning in which any trees, or any enumerated collection of trees, can be brought into view. Precisely as the trees understood in a totality, "the forest is the latent as such" (p. 332).

9. In the German idiom, this connection is reflected etymologically. There is an "ontological resonance" that "the concept "lived experience' has in itself and which binds it to words like "becoming aware' [Innewerden] and 'being aware' [Innesein]" (Gadamer, 1985, p. 167). The verb prefix "inne" belonge to the same cluster of words which, following Jacob Grimm, Heidegger traces to the preposition "in" (1977a, p. 54, n. 1). Existentially ontologically, it means what is "inward" in the sense of what one is or has become. It also means "to dwell" or "reside" in a world as that which is "familiar to me in such and such a way" and whose "familiarity" makes it a world.

10. Though Heidegger claims that "truth" and "meaning" are the "same" (Selbe), he distinguishes (1971a) the "same," in which there is essential difference-in-unity, and the "identical" (gleich), "the empty indifferent oneness ... in which everything may be reduced to a common denominator" (p. 218). This contrasts on the one hand with the extreme of positivism that reduces meaning to truth as tautology and correspondence, and on the other hand with the extreme of post-modernism that reduces truth to meaning as semiosis and intertextuality. In the phenome- 
nological account, however, it remains to be seen in this regard what is the difference that makes a difference.

Editor's comment: The use of the generic pronoun she is at the express wish of the author.

\section{References}

Barritt, L.S., Beekman, T., Bleeker, H., Mulderij, K. (1983). The world through children's eyes: Hide and seek \& peekaboo. Phenomenology + Pedagogy, 1(2), 140-161.

Brentano, F. (1928). Pyschologie vom empirischen Standpunkt I. Leipzig: Felix Meiner.

Buber, M. (1958). I and thou. New York: Charles Scribner's Sons. Burch, R. (1987). Conloquium interruptum: Stopping to think. In E. Simpson (Ed.), Anti-foundationalism and practical reasoning (pp. 99-119). Edmonton, AB: Academic Printing \& Publishing.

Burch, R. (1989). On phenomenology and its practices.

Phenomenology + Pedagogy, 7, 187-217.

Buytendijk, F.J.J. (1988). The first smile of the child. Phenomenology + Pedagogy, 6, 15-24.

Dilthey, W. (1927). Der Aufbau der Geschichtlichen Welt in den Geisteswissenschaften. Leipzig u. Berlin: B.G. Teubner.

Dilthey, W. (1985). Poetry and experience. Princeton, NJ: Princeton University Press.

Fackenheim, E.L. (1961). Metaphysics and historicity. Milwaukee, WI: Marquette University Press.

Fackenheim, E.L. (1968). Quest for past and future. Boston, MA: Beacon Press.

Fichte, J.G. (1970). Science of knowledge. New York: Appleton Century Crofts.

Gadamer, H.-G. (1975). Truth and method. New York: Seabury Press.

Gadamer, H.-G. (1977). Wieweit schreibt Sprache des Denken vor? Kleine Schriften IV. Tübingen: J.C.B. Mohr.

Gadamer, H.-G. (1985). Wilhelm Dilthey nach 150 Jahren. Dilthey und die Philosophie der Gegenwart, hrsg. E.W. Orth. Freiburg/Munchen: Verlag Karl Alber.

Grant, G. (1986). Technology \& justice. Toronto: Anansi.

Hegel, G.W.F. (1977). Hegel's phenomenology of spirit. Oxford, UK: Oxford University Press.

Hegel, G.W.F. (1978). Hegel's philosophy of subjective spirit. Boston, MA: Reidel.

Heidegger, M. (1955). Was ist Metaphysik? 6 Aufl. Frankfurt: Klostermann.

Heidegger, M. (1956). The way back into the ground of metaphysics. In W. Kaufmann (Ed.), Existentialism from Dostoevsky to Sartre (pp. 206-221). New York: Meridan Books.

Heidegger, M. (1959). An introduction to metaphysics. New Haven, CT: Yale University Press.

Heidegger, M. (1961). Neitzsche, Bd. I. Pfullingen: Neske. 
Heidegger, M. (1969). The essence of reasons. Evanston, IL: Northwestern University Press.

Heidegger, M. (1971a). Poetry, language and thought. New York: Harper \& Row.

Heidegger, M. (1971b). On the way to language. New York: Harper \& Row.

Heidegger, M. (1977a). Sein und Zeit. 13 Aufl. (with the author's marginal notes). Tübingen: Niemeyer.

Heidegger, M. (1977b). Basic writings. New York: Harper \& Row.

Hume, D. (1888). A treatise on human nature. Oxford, UK: Oxford University Press.

Husserl, E. (1970a). Cartesian meditations. The Hague: Nijhoff.

Husserl, E. (1970b). The crisis of European sciences and transcendental phenomenology. Evanston, $\mathrm{L}$ : Northwestern University Press.

James, W. (1890). The principles of psychology. Volumes I and II. New York: Dover Publications.

Jaspers, K (1948). Philosophie. 2. Aufl. Berlin-Göttingen -Heidelberg: Springer Verlag.

Kant, I. (1929). The critique of pure reason. New York: St. Martin's Press.

Koffka, K (1935). Principles of gestalt pyschology. New York: Harcourt, Brace \& World.

Lingis, A. (1986). Phenomenological explanations. Dordrecht: Nijhoff.

Macmurray, J. (1956). The self as agent. London: Faber \& Faber.

Merleau-Ponty, M. (1962). Phenomenology of perception. London: Routledge \& Kegan Paul.

Merleau-Ponty, M. (1964a). Le visible et l'invisible. Paris: Gallimard.

Merleau-Ponty, M. (1964b). Signes. Paris: Gallimard.

Merleau-Ponty, M. (1973). The prose of the world. Evanston, $\mathrm{L}$ : Northwestern University Press.

Ortega y Gasset, J. (1946). Meditaciones del Quijote. Obras Completas. Tomo 1 (1902-1916). Madrid: Revista de Occidente.

Ortega y Gasset, J. (1961). History as a system. New York: Norton.

Sartre, J.-P. (1956). Being and nothingness. New York: Philosophical Library.

Sartre, J.-P. (1970). L'existentialisme est un humanisme. Paris: Les éditions Nagels.

Scheler, M. (1961). Man's place in nature. New York: Noonday Press. Scheler, M. (1980). Der Formalismus in der Ethik und die Materiale Wertethik. 6. Aufl. Bern u. München: Francke Verlag.

Schutz, A. (1967). The phenomenology of the social world. Evanston, IL: Northwestern University Press.

van Manen, M. (1986). We need to show our human science is a relation of pedagogy. Phenomenology + Pedagogy, 4, 78-93.

van Manen, M. (1990). Researching lived experience: Human science for an action sensitive pedagogy. London, ON: Althouse Press; New York: SUNY Press. 